Portland State University

PDXScholar

Summer 2021

\title{
Comparing Instruments for Measuring Runoff from Experimental Ecoroof Platforms: A Case Study on Test Plots at Portland State University
}

Chance F. Hodges

Portland State University

Follow this and additional works at: https://pdxscholar.library.pdx.edu/honorstheses

Part of the Environmental Engineering Commons, and the Water Resource Management Commons Let us know how access to this document benefits you.

Recommended Citation

Hodges, Chance F., "Comparing Instruments for Measuring Runoff from Experimental Ecoroof Platforms: A Case Study on Test Plots at Portland State University" (2021). University Honors Theses. Paper 1140. https://doi.org/10.15760/honors.1170

This Thesis is brought to you for free and open access. It has been accepted for inclusion in University Honors Theses by an authorized administrator of PDXScholar. Please contact us if we can make this document more accessible: pdxscholar@pdx.edu. 


\title{
Comparing Instruments for Measuring Runoff from Experimental Ecoroof Platforms: A Case Study on Test Plots at Portland State University
}

\author{
By \\ Chance Hodges \\ An undergraduate honors thesis submitted in partial fulfillment of the requirements for the \\ degree of Bachelor of Science \\ in \\ Environmental Engineering \\ and \\ University Honors \\ Thesis Advisor \\ Olyssa Starry, Ph.D. \\ Co-Advisor \\ Samantha Hartzell \\ Portland State University \\ 2021
}




\section{Acknowledgements}

Thank you first and foremost to Olyssa Starry for advising me throughout this thesis experience, it would not be possible without you. Thank you to Samantha Hartzell of the Civil and Environmental Engineering department for your co-advising on alternatives, particularly the $\mathrm{H}$-flume. Thank you to Tom Bennett of the Civil and Environmental Engineering department for calibration of the $\mathrm{H}$-flume. Thank you to my classmates, Madison Whitlow-Hewett and David Jones, for help with the $\mathrm{H}$-flume calibration and custom tipping bucket consultation. Lastly, thank you to everyone who has supported me along the way. This thesis work would not be nearly as enriching without all your help and guidance.

\section{Table of Contents}

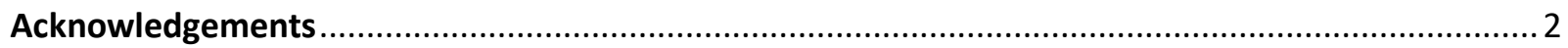

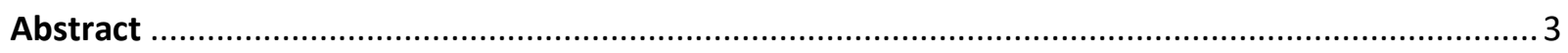

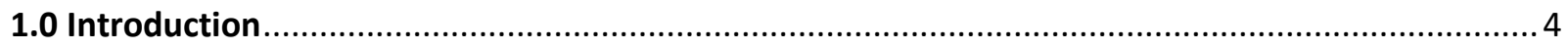

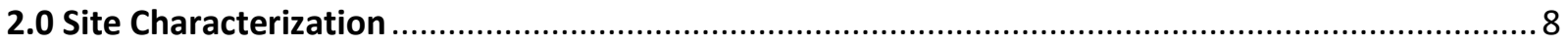

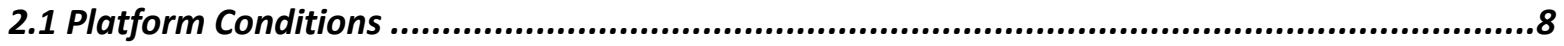

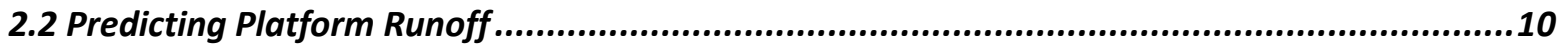

2.2.1 Rainfall Characterization using the Portland IDF-Curve........................................................ 10

2.2.2 Rainfall Characterization using USGS Rainfall Data............................................................. 13

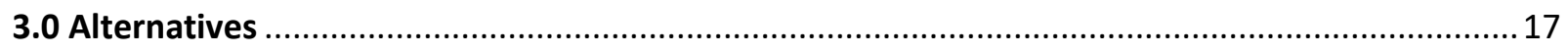

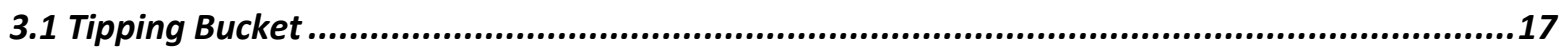

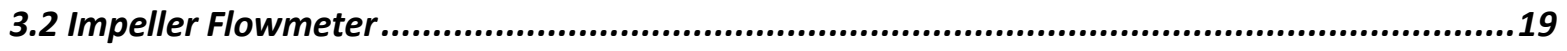

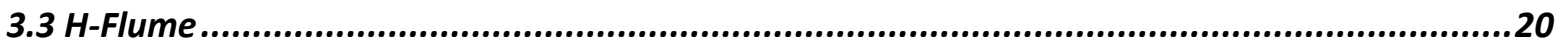

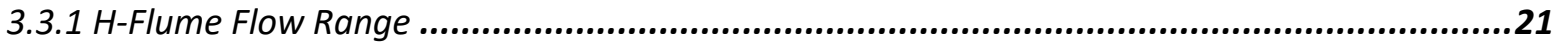

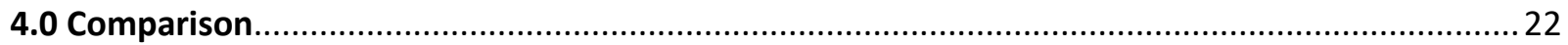

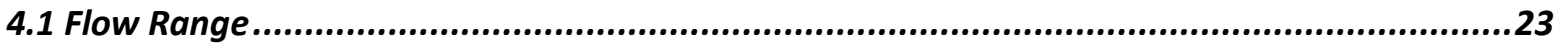

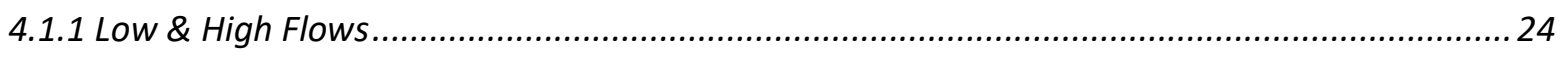

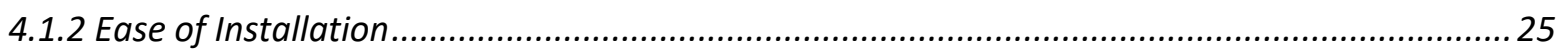

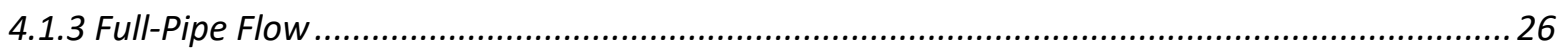

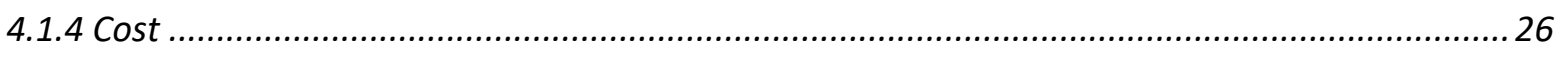

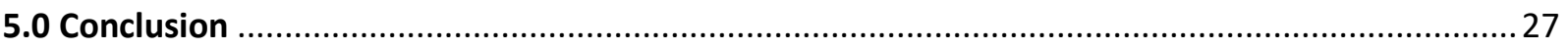

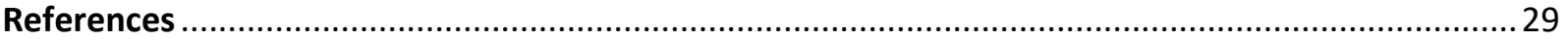




\section{Abstract}

Stormwater management is a primary ecological benefit ecoroofs provide to ecosystems. Quantification of runoff from large scale ecoroofs is difficult to replicate, so researchers often utilize smaller experimental ecoroof platforms. This approach is becoming increasingly common, so it is useful to compare and contrast approaches for runoff measurement at the platform scale. This paper uses the four $17.86 \mathrm{~m}^{2}$ ecoroof platforms located on the Science Research and Teaching Center (SRTC) at Portland State University (PSU) in Portland, OR as a case study. A unique condition of these platforms is that they are installed at grade on the roof with no elevation. The expected runoff flow rate range from the SRTC ecoroof platforms was estimated using long-term hydrologic data and site geometry and was determined as $0.001 \mathrm{~L} / \mathrm{s}$ to $0.170 \mathrm{~L} / \mathrm{s}$. Majority of the expected flow rates fall between $1 \mathrm{~mL} / \mathrm{s}$ and 5 $\mathrm{mL} / \mathrm{s}$, so instrumentation that can capture these flow flows is of priority. Assuming that $0 \%$ retention is a possibility in the wet season, the runoff instrumentation should ideally be designed to capture flow rates as high as $170 \mathrm{~mL} / \mathrm{s}$. The alternatives explored were a tipping bucket rain gage, an impeller flowmeter, and an H-flume. Instruments were compared based on their ability to capture expected flow, installation requirements, and cost. This work suggests that the most effective solution for low-flow measurement for this site is a custom tipping bucket designed for the expected flow rates because all other solutions do not capture the full expected flow range. As an alternative, a combination of devices, such as a tipping bucket linked to a flume, can be considered to capture both peak flow and low flows. Future efforts should focus on adaptable yet effective instrumentation that can accommodate various platform installations. 


\subsection{Introduction}

The rapid growth of urban areas over the past couple centuries has resulted in an overwhelming demand on stormwater management systems. This rapid urbanization increases impervious surfaces such as roads and rooftops, typically made of asphalt or concrete, while decreasing natural absorbent land via deforestation and habitat destruction. Such impervious surfaces prevent rainwater from percolating into the soil for groundwater recharge, resulting in both increased runoff quantity and decreased water quality (Brabec et al., 2002). Increased runoff contributes to transport of pollutants such as particulate matter, heavy metals, organic contaminants, and nutrients which degrade watershed quality and damage ecosystems. Higher amounts of runoff can also overwhelm urban drainage systems, resulting in urban flooding (Karamouz et al., 2011).

The degradation of watershed quality and increased runoff from urbanization prompted the Clean Water Act to be passed in 1972, which requires municipal discharge to adhere to a local National Pollutant Discharge Elimination System (NPDES) permit. The City of Portland NPDES permit requires new development and redevelopment to meet certain conditions, including the prioritization of green infrastructure for runoff control (NPDES MS4 Discharge Permit 2011). Green infrastructure is any form of stormwater management with the intent to mimic the natural water cycle, often consisting of soil and vegetation. One common form of green infrastructure are ecoroofs. From bottom to top, a typical ecoroof consists of a waterproof membrane, a drainage layer, growing medium, and drought tolerant vegetation such as sedum (Figure 1). Stormwater percolates down to the waterproof membrane and drains to an approved roof drainage system. This process filters, slows, and even retains stormwater thus reducing load on stormwater systems (Bureau of Environmental Services 2020). 


\section{ECOROOF WITH DRAINAGE LAYER}

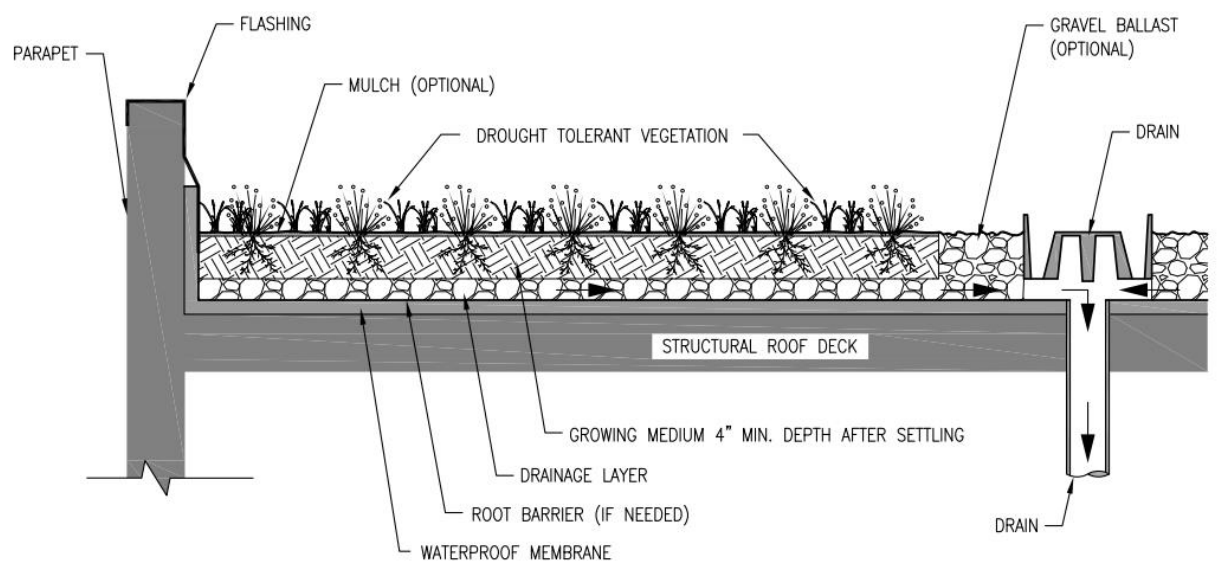

Figure 1. Cross-section side view of a generic ecoroof with a drainage layer (Bureau of Environmental Services 2020).

Ecoroof efficiency is often determined using runoff data paired with local rainfall data.

Therefore, runoff quantification is of particular interest in measuring the performance of ecoroofs. Instrumentation for runoff measurement varies depending on factors including roof scale, location hydrology, and purpose of the research. A variety of methods are used, including tipping bucket rain gages, flumes, weirs, and electromagnetic flowmeters. Even among flumes and weirs, varying geometries and water-level sensors have been used.

Large scale ecoroofs in the Pacific Northwest monitor runoff using a range of these methodsFor example, the ecoroofs located on the Hamilton Apartments in Portland, Oregon use V-trapezoidal flumes with a bubbler-type flow meter to measure water level (Hutchinson et al., 2003). The Multnomah County Building and Broadway Building in Portland, Oregon, use electromagnetic flowmeters that require full flooding for accurate flow measurements (Spolek, 2008). In contrast to these single-stage runoff monitoring systems, some studies have implemented two-stage monitoring systems to capture a wider range of flows. For two ecoroofs in Seattle, Washington, runoff is first directed through a 
magnetic flowmeter before passing into a tipping bucket. The magnetic flowmeter allows for measurement of medium to high flows, while the tipping bucket allows for measurement of low flows. Another ecoroof in Seattle, Washington uses a two-stage monitoring system that routes runoff through a tipping bucket which drains into an HS flume. The HS flume allows for measurement of higher flows while the tipping bucket allows for measurement of low flow. Another Seattle ecoroof uses customdesigned insert devices consisting of several orifices. (Berkompas et al., 2008).

It is difficult to measure runoff on the roof-scale, so smaller ecoroof platforms are often used for studies that can be extrapolated to the roof-scale. These smaller platforms are often raised beds and typically measure lower volumes of runoff. Research done at the University of Maryland measured runoff from raised experimental ecoroof platforms using tipping bucket rain gages. The study initially began using the Decagon (ECRN-50) low-volume rain gage before switching to a higher capacity doubletip rain gage due to higher storm intensities (Starry, 2013). A study at the Michigan State University Horticulture Teaching and Research Center also uses tipping bucket rain gages to measure stormwater runoff from ecoroof platforms. The TE525WS model tipping buckets were placed beneath the drain of each raised platform (Rowe, 2005). While tipping buckets are common, another method used is directing runoff to a collection tank. One study using raised experimental ecoroof platforms at the University of Toronto's Green Roof Innovation Testing Laboratory (GRIT Lab) measured runoff using a collection tank, weighing lysimeter, and a water-balance model (Jahanfar et al., 2018). Another study on larger raised platforms at the GRIT Lab measured runoff using a tipping bucket (Maclvor et al., 2013). A study at the University of Hong Kong directed discharge from raised ecoroof platforms into a custommade covered tank that was continuously weighed by the second (Wong \& Jim, 2014). Review of the literature reveals that runoff monitoring systems vary widely among studies and depend on factors including the ecoroof scale and local hydrology. Typically, flumes, weirs, and electromagnetic flowmeters are used more often in roof-scale monitoring, while collection tanks are used more often for 
small-scale experimental platforms. Tipping buckets have been used for both roof and experimental scale studies (Table 1).

Table 1. Summary of literature review by experimental scale, area, location, and instrumentation for runoff measurement.

*The total area of 3 individual platforms was $5.95 \mathrm{~m}^{2}$, each with their own tipping bucket.

\begin{tabular}{|c|c|c|c|c|}
\hline Study & Scale & Area $(\mathrm{m} 2)$ & Location & Instrumentation \\
\hline $\begin{array}{l}\text { Hutchinson et al., } \\
2003\end{array}$ & Roof & 478 & Portland, OR & V-trapezoidal Flume \\
\hline Spolek, 2008 & Roof & $280-500$ & Portland, OR & Electromagnetic Flowmeter \\
\hline \multirow{2}{*}{$\begin{array}{l}\text { Berkompas et al., } \\
2008\end{array}$} & Roof & $595-743$ & Seattle, WA & $\begin{array}{c}\text { Electromagnetic Flowmeter + } \\
\text { Tipping Bucket }\end{array}$ \\
\hline & Roof & 81 & Seattle, WA & Tipping Bucket + HS-Flume \\
\hline Starry, 2013 & Experimental & 1.31 & College Park, MD & Tipping Bucket \\
\hline Rowe, 2005 & Experimental & $5.95^{*}$ & Holt, MI & Tipping Bucket \\
\hline Maclvor et al., 2013 & Experimental & 2.88 & Toronto, Canada & Tipping Bucket \\
\hline $\begin{array}{c}\text { Jahanfar et al., } \\
2018\end{array}$ & Experimental & 0.194 & Toronto, Canada & Lysimeter + Collection Bucket \\
\hline Wong \& Jim, 2014 & Experimental & 1.1 & $\begin{array}{l}\text { Pok Fu Lam, } \\
\text { Hong Kong }\end{array}$ & Collection Bucket \\
\hline
\end{tabular}

Currently, Portland State University (PSU) has four $17.86 \mathrm{~m}^{2}$ experimental ecoroof platforms on the Science Research and Teaching Center (SRTC) rooftop that do not currently have instrumentation for runoff measurement. The ecoroof platforms of concern are not elevated, making it difficult to install a tipping bucket or collection tank beneath the drainage pipe as previous studies have done. The purpose of this work is to evaluate possible instrumentation for runoff measurement from the experimental ecoroof platforms located on the SRTC rooftop at PSU. This will be done by 1) characterizing the local hydrology to determine expected flows through the platforms and 2) comparing different instrumentation based on the following criteria: ability to measure expected flows, ease of installation, specification for low or high flows, full-pipe flow requirement, and expense. 


\subsection{Site Characterization}

The hydrology of the site and geometry of the ecoroof platforms are necessary to determine expected runoff patterns of the ecoroof platforms. This section aims outline platform conditions and quantify expected runoff flow rates. The expected flow from the ecoroof platforms is necessary for equipment selection as flow measurement devices are designed to operate at a specific range of flows. Expected runoff flow range will be determined using local IDF curve data and long-term USGS precipitation data.

\subsection{Platform Conditions}

The four ecoroof platforms are located on the SRTC building on PSU campus in Portland, Oregon. Each ecoroof platform is approximately $4.7 \mathrm{~m} \times 3.8 \mathrm{~m}$, resulting in an area of $17.86 \mathrm{~m}^{2}$ each (Figure 3). Currently, outflow from the platforms is directed through a single pipe that drains onto the concrete rooftop. The ecoroof platforms are not elevated, so the outflow pipe sits directly on the concrete rooftop. Each testbed has 4 overflow pipes with $8 \mathrm{~cm}$ between the concrete rooftop and the bottom of the pipe (Figure 4). 


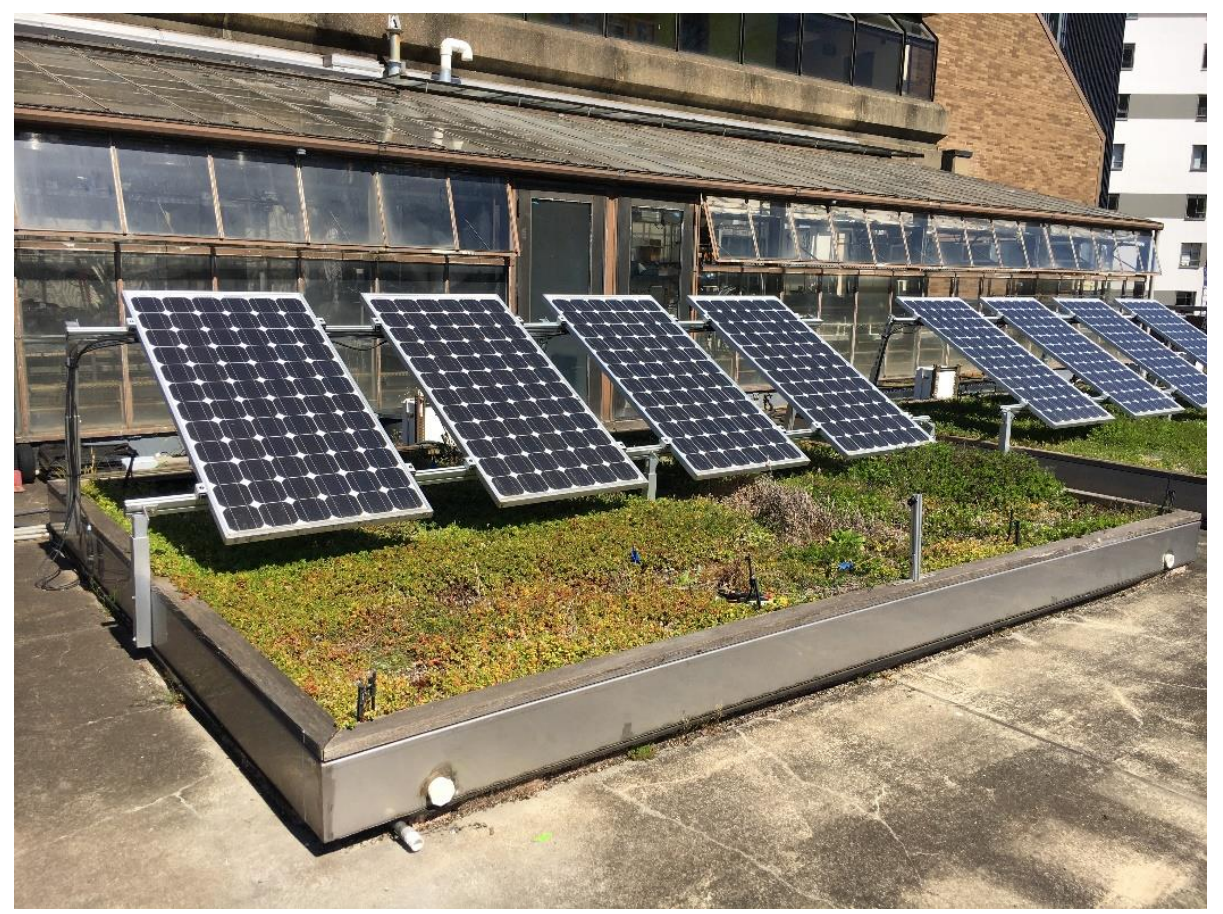

Figure 3. Experimental ecoroof platform on the SRTC rooftop (Facing Northeast).

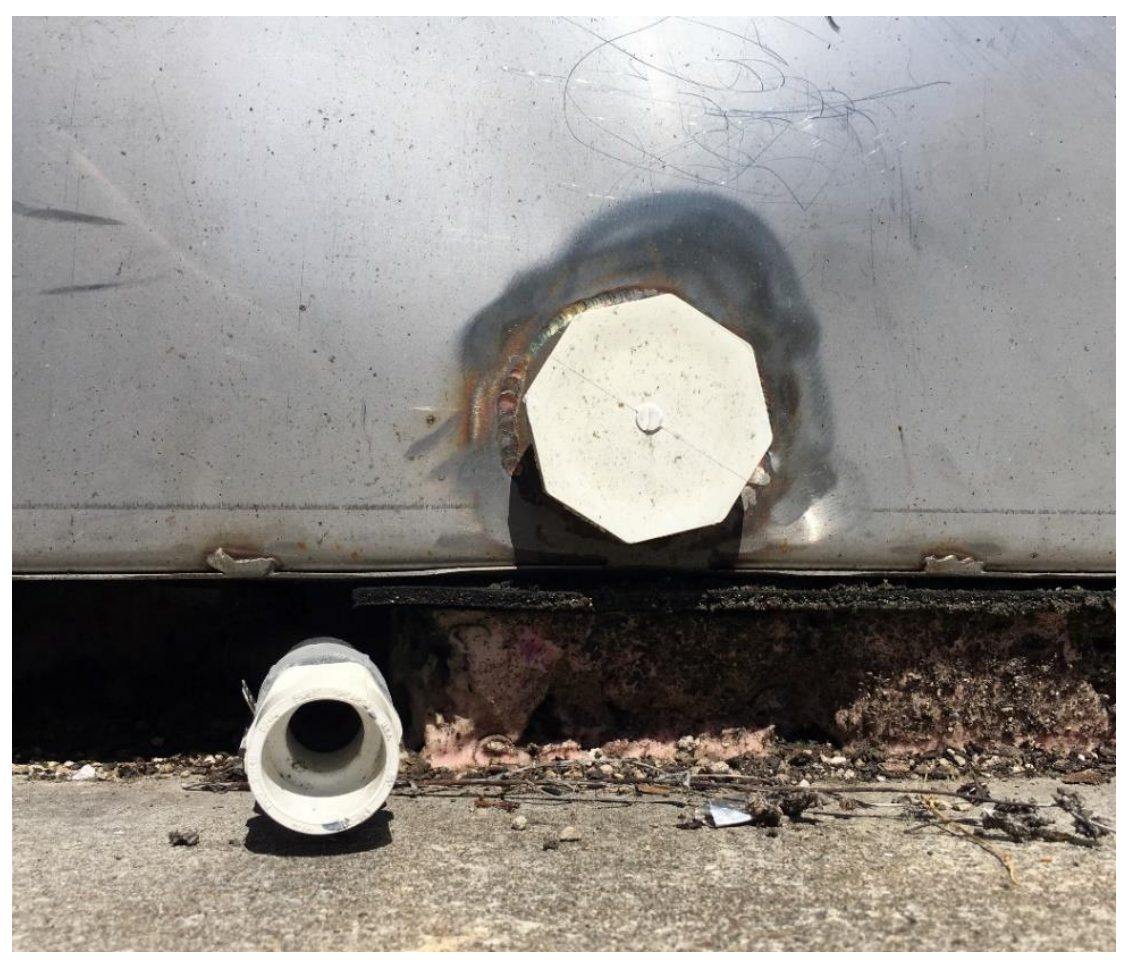

Figure 4. Closeup of outflow pipe and one closed overflow pipe. 


\subsection{Predicting Platform Runoff}

Runoff is often measured in units of volume $(\forall)$ per time $(t)$ which is generally referred to as flow. The rainfall rate onto a single platform can be calculated by multiplying the intensity $(i)$ in depth per time by the platform area:

$$
Q=\frac{\forall}{t}=i * A
$$

Equation 1.

This principle will be used throughout this section to calculate expected runoff flows through the experimental ecoroof platforms. For the SRTC platforms, $A=17.86 \mathrm{~m}^{2}$. Rainfall intensity from longterm USGS data will be converted from in/hr to $\mathrm{m} / \mathrm{s}$ using the conversion factor $1 \mathrm{~m}=39.2701$ in before plugging into Equation 1 for unit consistency. The resulting flow values in $\mathrm{m}^{3} / \mathrm{s}$ will be converted to L/s using the conversion factor $1 \mathrm{~m}^{3}=1000 \mathrm{~L}$ such that all flow rates are compared in the same units. Ecoroof platforms often retain some percentage of rainfall, so the incoming rainfall flow will be referred to as "rainfall rate" while the flow through the platform will be referred to as "runoff flow".

\subsubsection{Rainfall Characterization using the Portland IDF-Curve}

An Intensity-Duration-Frequency (IDF) curve relates the duration of a storm and the probability a given storm will occur to rainfall intensity for storms with different recurrence intervals, or return periods. Frequency is interpreted as the probability a storm will occur within a given time span, otherwise known as return period. For example, a 100 -year storm has a $1 \%$ chance it will occur any given year. Similarly, a 2-year storm has a $50 \%$ chance it will occur any given year. In other words, the intensity of a storm at a given return period and duration can be predicted. IDF curves are based off long-term historical precipitation data. The IDF curve plots lines representing a storm of given frequency 
with duration in minutes on the $x$-axis and rainfall intensity in in/hr. on the y-axis. In this study, the Portland, Oregon IDF curve will be used to guide equipment selection (Figure 4).

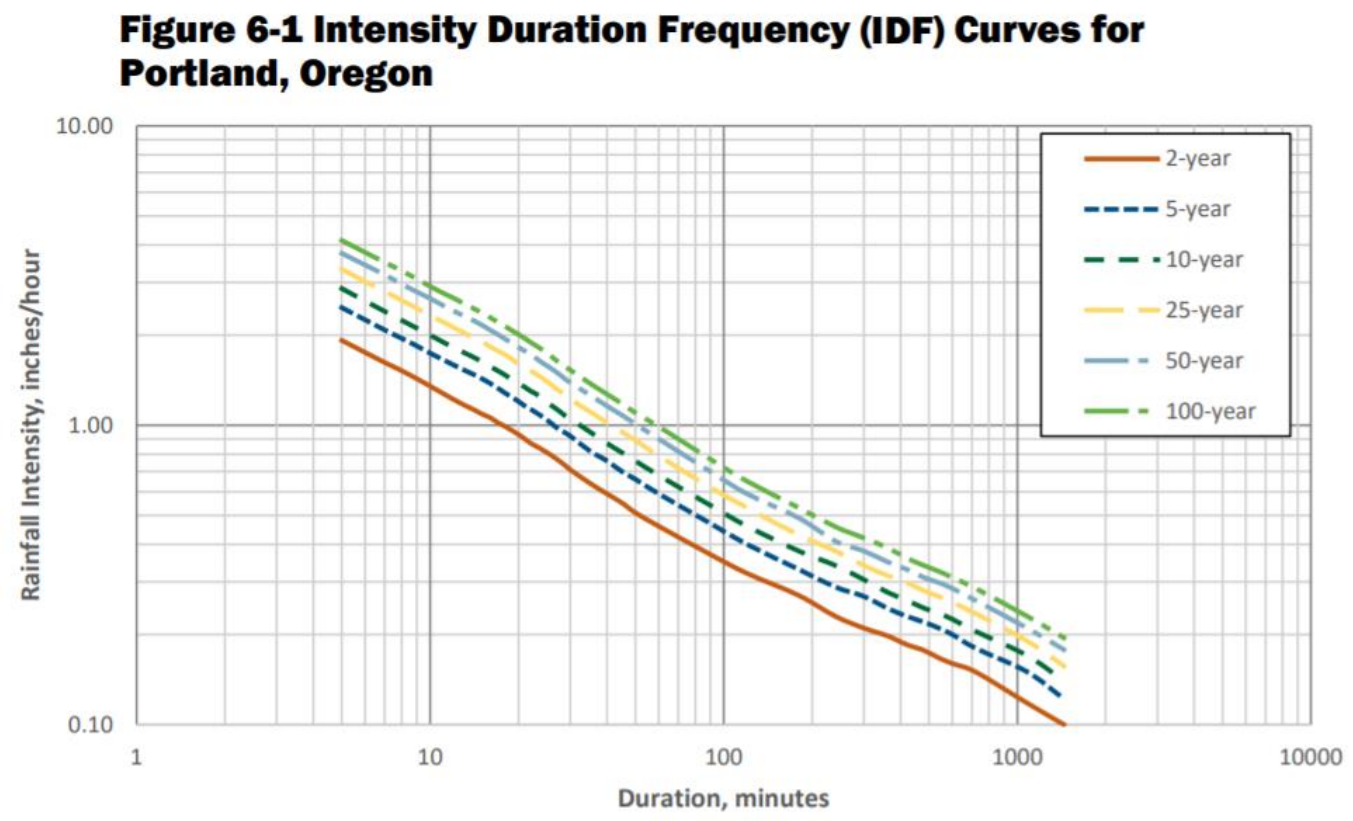

Figure 4. Portland, Oregon IDF curve (City of Portland Bureau of Environmental Services, 2020).

Since a 100 -year storm is an extremely rare event, 100 -year storm flows need not be prioritized in equipment selection. However, a 2-year storm is more common, so equipment should be selected that can capture these flows. The expected maximum rainfalls intensities at 10,100 , and 1000 minute durations for 2-year, 25-year, and 100-year storms were read from the City of Portland Bureau of Environmental Services IDF data. These values intensity values were converted from in/hr to $\mathrm{m} / \mathrm{s}$ and plugged into Equation 1 where $\mathrm{A}$ is equal to the area of a single ecoroof platform, resulting in estimated rainfall flow values through a single platform at the given intensities and frequencies. All values were converted to L/s (Table 2). 
Table 2. Expected rainfall flow values through a platform for 10, 100, and 1000 minute storms at given frequencies.

\begin{tabular}{c|ccc}
\cline { 2 - 4 } \multicolumn{1}{c|}{$\begin{array}{c}\text { Duration } \\
\text { (min) }\end{array}$} & 10 & 100 & 1000 \\
\cline { 2 - 4 } Frequency & & 0.045 & 0.018 \\
\hline 2-year & 0.170 & 0.074 & 0.028 \\
25 -year & 0.292 & 0.092 & 0.034 \\
100-year & 0.367 & 0.092 & \\
\hline
\end{tabular}

If the ecoroof platforms are assumed to retain $0 \%$ of the rainfall, then the rainfall flowrates are equal to the ecoroof runoff flowrates. Ecoroofs typically retain a percentage of rainfall, so ecoroof runoff flowrates based on the IDF curve were determined for $25 \%$ and $50 \%$ retention rates based on retention rates determined in the literature (Spolek, 2008) (Table 3).

Table 3. Expected platform runoff flows at given durations and frequencies at $0 \%, 25 \%$, and $50 \%$ retention rates.

\begin{tabular}{|c|c|c|c|c|c|c|c|c|c|}
\hline \multirow{3}{*}{$\begin{array}{l}\text { Duration } \\
\text { (min) }\end{array}$} & \multicolumn{3}{|c|}{$0 \%$ Retention } & \multicolumn{3}{|c|}{$25 \%$ Retention } & \multicolumn{3}{|c|}{$50 \%$ Retention } \\
\hline & \multicolumn{3}{|c|}{ Runoff Flow (L/s) } & \multicolumn{3}{|c|}{ Runoff Flow (L/s) } & \multicolumn{3}{|c|}{ Runoff Flow (L/s) } \\
\hline & \multirow[t]{2}{*}{10} & \multirow[t]{2}{*}{100} & \multirow[t]{2}{*}{1000} & \multirow[t]{2}{*}{10} & \multirow[t]{2}{*}{100} & \multirow[t]{2}{*}{1000} & \multirow[t]{2}{*}{10} & \multirow[t]{2}{*}{100} & \multirow[t]{2}{*}{1000} \\
\hline Frequency & & & & & & & & & \\
\hline 2-year & 0.170 & 0.045 & 0.018 & 0.128 & 0.034 & 0.013 & 0.085 & 0.023 & 0.009 \\
\hline 25-year & 0.292 & 0.074 & 0.028 & 0.219 & 0.056 & 0.021 & 0.146 & 0.037 & 0.014 \\
\hline 100-year & 0.367 & 0.092 & 0.034 & 0.275 & 0.069 & 0.026 & 0.183 & 0.046 & 0.017 \\
\hline
\end{tabular}


Based on the IDF curve and assumed retention rates, expected runoff flows may range from $0.009 \mathrm{~L} / \mathrm{s}$ to $0.367 \mathrm{~L} / \mathrm{s}$ for all considered durations and frequencies. However, if 25-year and 100-year storms are neglected as outliers, expected flows for a 2-year storm may range from $0.009 \mathrm{~L} / \mathrm{s}$ to 0.170 $\mathrm{L} / \mathrm{s}$ depending on the intensity and retention rate. Assuming that $0 \%$ retention is a possibility in the wet season, the runoff instrumentation should ideally be designed to capture flow rates as high as $0.170 \mathrm{~L} / \mathrm{s}$ based on these estimations.

\subsubsection{Rainfall Characterization using USGS Rainfall Data}

Hourly rainfall data at the Portland Airport collected by USGS was used to predict the most common rainfall intensities. USGS collected data using a tipping bucket rain gage where 1 tip $=0.01$ in of rainfall. Rainfall data from January $1^{\text {st }}, 2015$ - October $23^{\text {rd }}, 2020$, was analyzed in excel by counting how often rainfall intensities occurred within a specific range (Table 4). 
Table 4. Total tip counts for each range from January 2015 to October 2020.

\begin{tabular}{cc}
\hline $\begin{array}{c}\text { Intensity } \\
\text { (tips) }\end{array}$ & Total Occurrences \\
\hline 1 to 10 & 5920 \\
11 to 20 & 558 \\
21 to 30 & 158 \\
31 to 40 & 106 \\
41 to 50 & 50 \\
51 to 60 & 41 \\
61 to 70 & 23 \\
71 to 80 & 28 \\
81 to 90 & 11 \\
91 to 100 & 17 \\
100 to 150 & 17 \\
150 to 200 & 8 \\
200 to 250 & 3 \\
250 to 300 & 2 \\
\hline
\end{tabular}

The tip ranges were converted to in/hr. using $1 \mathrm{tip}=0.01 \mathrm{in} / \mathrm{hr}$. Intensity values were converted from in/hr to $\mathrm{m} / \mathrm{s}$ and plugged into Equation 1 where $A$ is equal to the area of a single ecoroof platform, resulting in estimated rainfall flow values, or $\mathrm{Q}$ in Equation 1, through a single platform at corresponding rainfall intensity ranges. All values were converted to $\mathrm{L} / \mathrm{s}$ (Table 5). Intensity range distribution is depicted in Figure 5. 
Table 5. Expected rainfall flow rates based on USGS rainfall intensity data with respective occurrences from January 2015 to October 2020.

\begin{tabular}{|c|c|c|}
\hline \multicolumn{2}{|c|}{ Rainfall Rate (L/s) } & Occurrences \\
\hline Lower & Upper & \\
\hline Bound & Bound & (Since Jan 2015 to Oct 2020) \\
\hline 0.001 & 0.013 & 5920 \\
\hline 0.014 & 0.025 & 558 \\
\hline 0.026 & 0.038 & 158 \\
\hline 0.039 & 0.050 & 106 \\
\hline 0.052 & 0.063 & 50 \\
\hline 0.064 & 0.076 & 41 \\
\hline 0.077 & 0.088 & 23 \\
\hline 0.089 & 0.101 & 28 \\
\hline 0.102 & 0.113 & 11 \\
\hline 0.115 & 0.126 & 17 \\
\hline 0.127 & 0.189 & 17 \\
\hline 0.190 & 0.252 & 8 \\
\hline 0.253 & 0.315 & 3 \\
\hline 0.316 & 0.378 & 2 \\
\hline
\end{tabular}

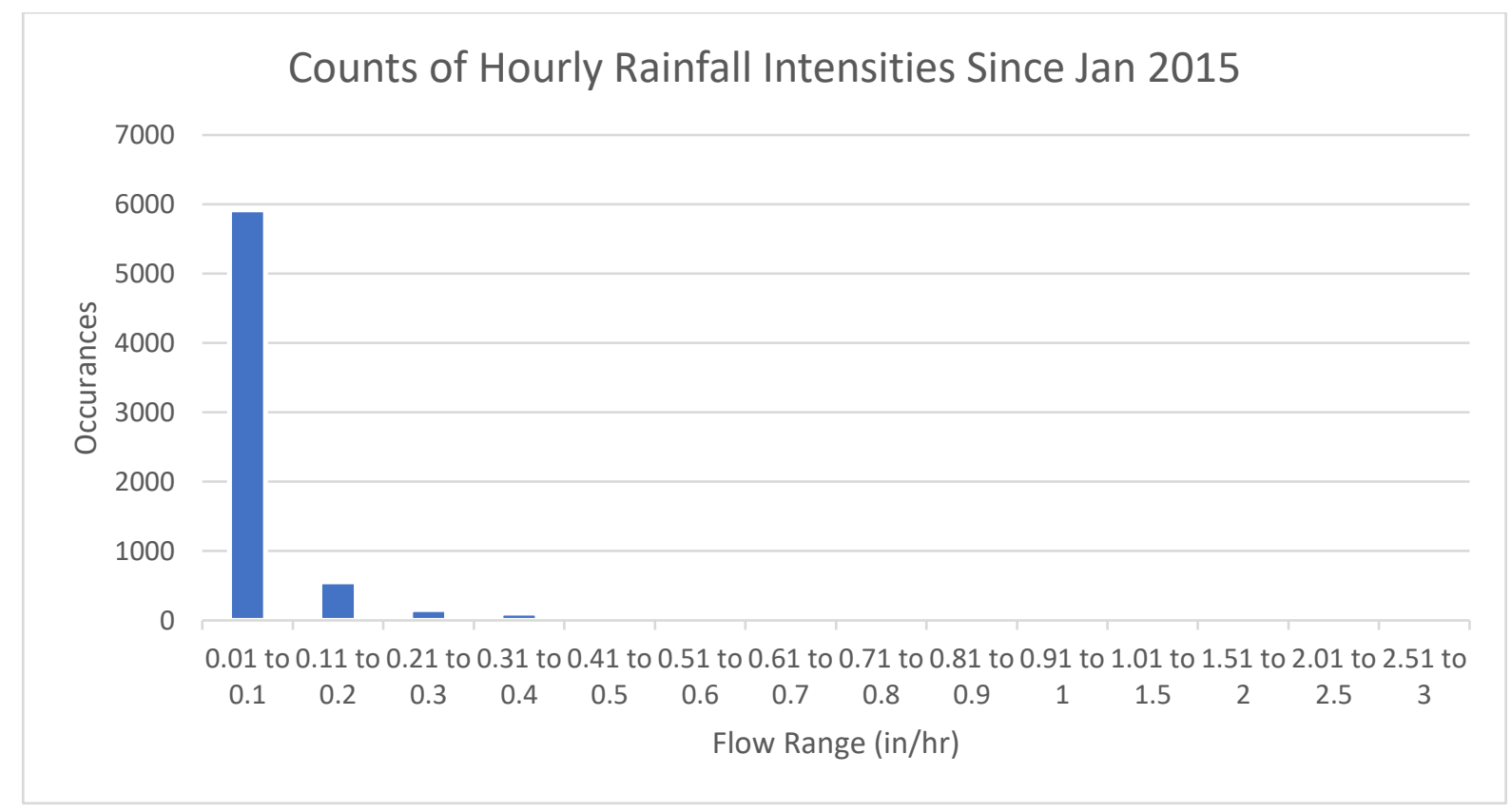

Figure 5. Occurrences of hourly rainfall flow ranges in in/hr. from Jan 2015 to Oct 2020. 
The data shows that rainfall flowrates onto a single experimental ecoroof platform typically fall in the lowest range of 0.001 to $0.013 \mathrm{~L} / \mathrm{s}$ which corresponds to rainfall intensities of 0.01 to $0.1 \mathrm{in} / \mathrm{hr}$. If the ecoroof platforms are assumed to retain $0 \%$ of the rainfall, then the rainfall flowrates are equal to the platform runoff flowrates. The range of most common flows based on USGS rainfall data were determined for $25 \%$ and $50 \%$ retention rates (Table 6 ).

Table 6. Most common range of flows through ecoroof platforms at 0\%, 25\%, and 50\% retention.

\begin{tabular}{cc|cc|cc}
\hline \multicolumn{2}{c|}{ 0\% Retention } & \multicolumn{2}{c|}{ Runoff Flow (L/s) } \\
Lower Bound & Upper Bound & Lower Bound & Upper Bound & Lower Bound & Upper Bound \\
\hline 0.001 & 0.013 & 0.001 & 0.009 & 0.001 & 0.006 \\
\hline
\end{tabular}

The rainfall intensities of 0.01 to $0.1 \mathrm{in} / \mathrm{hr}$. make up majority of the hourly rainfall rates in the data, so this range was magnified for further evaluation. The number of occurrences of the values within this range in increments of $0.01 \mathrm{in} / \mathrm{hr}$. were determined (Table 7). $75 \%$ of occurrences in the 0.01 to 0.05 in/hr. range, so flow rates corresponding to these intensities should be prioritized in equipment selection. (Figure 6).

Table 7. Intensity from 0.01 to $0.1 \mathrm{in} / \mathrm{hr}$. converted to L/s with their respective occurrences from January 2015 to October 2020.

\begin{tabular}{ccc}
\hline Intensity (in/hr.) & Rainfall Rate L/s & $\begin{array}{c}\text { Total } \\
\text { Occurrences }\end{array}$ \\
\hline 0.01 & 0.001 & 2241 \\
0.02 & 0.003 & 999 \\
0.03 & 0.004 & 693 \\
0.04 & 0.005 & 518 \\
0.05 & 0.006 & 398 \\
0.06 & 0.008 & 321 \\
0.07 & 0.009 & 267 \\
0.08 & 0.010 & 209 \\
0.09 & 0.011 & 148 \\
0.1 & 0.013 & 126 \\
\hline
\end{tabular}




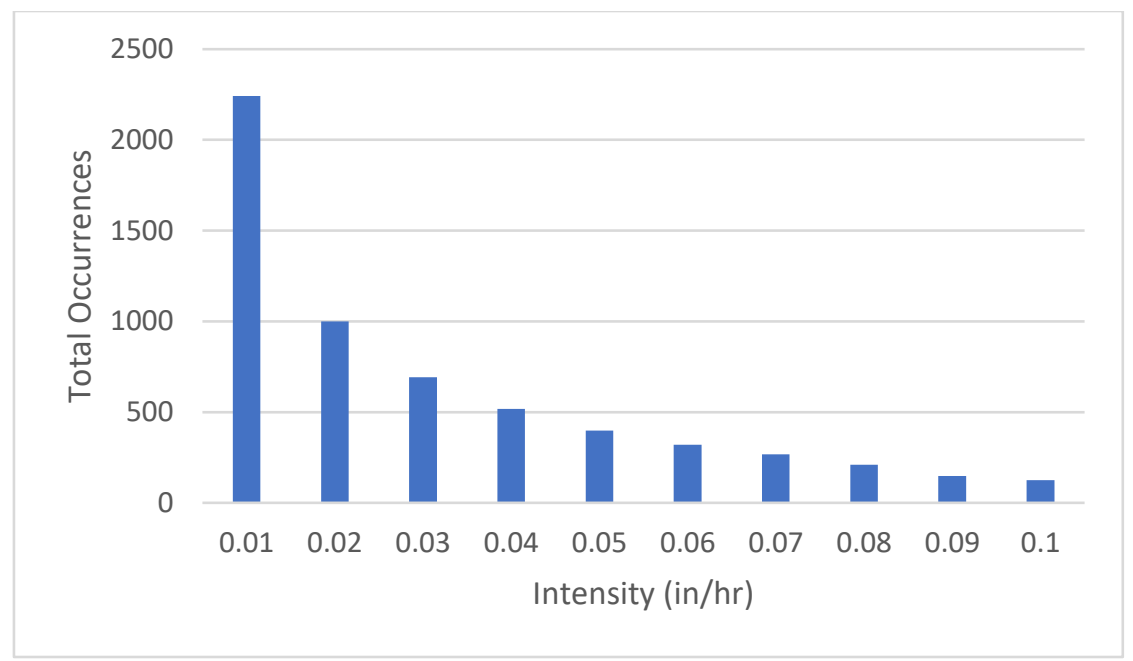

Figure 5. Occurrences of hourly rainfall flow ranges from 0.01 to $0.1 \mathrm{in} / \mathrm{hr}$. from Jan 2015 to Oct 2020

Based on the Portland IDF curve data for a 2-year storm and the Portland USGS rainfall data, expected runoff flows should range from $0.001 \mathrm{~L} / \mathrm{s}$ to $0.170 \mathrm{~L} / \mathrm{s}$. The most common runoff flows range from $0.001 \mathrm{~L} / \mathrm{s}$ to $0.005 \mathrm{~L} / \mathrm{s}$. Therefore, any recommended equipment must be specified for this low flow range, and will ideally also be able to detect higher flows up to $0.170 \mathrm{~L} / \mathrm{s}$.

\subsection{Alternatives}

The literature shows that many different methods are available for runoff flow measurement. This work will explore three options for the SRTC ecoroof platforms: tipping buckets, impeller flowmeters, and H-flumes. These instruments were chosen due to use in the literature and availability.

\subsection{Tipping Bucket}

A simple method for measuring runoff is the tipping bucket. Tipping buckets work by collecting water, typically rainfall, through a funnel opening. The water falls into one side of a seesaw-like "bucket" until that bucket is filled. At capacity, the bucket will tip the water down into a drain hole which prompts a sensor to record a count (Figure 2). The count recorded corresponds to a volume of water that varies 
depending on the tipping bucket rain gage. This volume is usually normalized by the area of the funnel opening and recorded in units of depth.

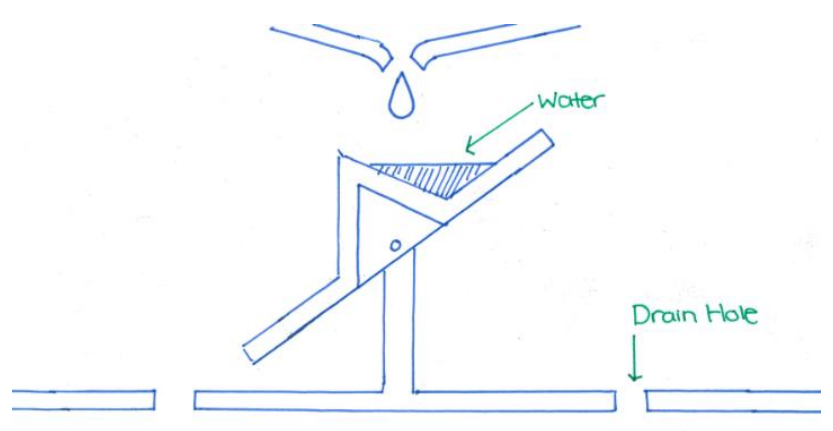

Figure 2. Diagram of general tipping bucket rain gage interior.

The device explored for this study is the Decagon (ECRN-50) tipping bucket rain gage. This model was chosen for its size and availability of existing data loggers. The Decagon (ECRN-50) has a precision, or resolution, of $1 \mathrm{~mm} /$ tip, or $5.0 \mathrm{~mL} /$ tip in volumetric units. The maximum tipping rate is $12 \mathrm{~mm} / \mathrm{min}$. Using dimensional analysis, the resolution and maximum tipping rate were using to find the minimum and maximum measurable flow rates of $0.0004 \mathrm{~L} / \mathrm{s}$ and $0.005 \mathrm{~L} / \mathrm{s}$, respectively. This instrument will allow for measurement of the prioritized flow ranges of $0.001 \mathrm{~L} / \mathrm{s}$ to $0.005 \mathrm{~L} / \mathrm{s}$. However, it will not give accurate readings for any higher flow rates.

To estimate the proportion of rainfall detectable by this instrument at the site, the 5-year USGS rainfall data was compared to the measurable flow range of the Decagon (ECRN-50). This was done by converting the measurable flow range to intensity by dividing by a single ecoroof platform's area and converting to in/hr. This resulted in a detectable intensity range of $0.003 \mathrm{in} / \mathrm{hr}$. to $0.04 \mathrm{in} / \mathrm{hr}$. The 5 -year USGS hourly intensity data was analyzed in excel to sum only those data points within this range. The inches of rainfall over the 5-year period at the USGS Portland Airport rain gage totaled to 493.3 inches, while the readings above $20 \mathrm{in} / \mathrm{hr}$. totaled to $187.0 \mathrm{in}$. Use of the Decagon (ECRN-50) tipping bucket 
would therefore miss 306.3 inches of rain, or $62.1 \%$ of the total volume of rainfall captured by the platforms.

\subsection{Impeller Flowmeter}

Another alternative explored is the impeller flowmeter. The impeller flow meter measures velocity of the water using an impeller and relates this to flow using the area of the orifice. One impeller flowmeter, the Omega (FPR300), can measure a flow range of $0.0045 \mathrm{~L} / \mathrm{s}$ to $0.315 \mathrm{~L} / \mathrm{s}$. The Omega (FPR300) measures higher flows that the Decagon (ECRN-50) cannot, so it may be suitable for a twostage monitoring system with the Decagon (ECRN-50). The Omega (FP-5060) impeller flowmeter can measure a lower flow range of $0.002 \mathrm{~L} / \mathrm{s}$ to $0.043 \mathrm{~L} / \mathrm{s}$. Another model, the Omega (FTB300) can measure an even lower flow range of $0.0005 \mathrm{~L} / \mathrm{s}$ to $0.005 \mathrm{~L} / \mathrm{s}$. There are no foreseen geometrical obstacles to installation of the impeller flowmeter. However, the impeller flowmeters require full-pipe flow which is not expected from low intermittent rainfall.

The proportion of rainfall detectable by the Omega (FPR300) was estimated by comparing the 5year USGS rainfall data to the measurable flow range of the Omega (FPR300). Converting the detectable flow range to intensity resulted in a detectable intensity range of $0.036 \mathrm{in} / \mathrm{hr}$. to $2.50 \mathrm{in} / \mathrm{hr}$. The inches of rainfall over the 5-year period at the USGS Portland Airport rain gage totaled to 493.3 inches, while the readings above $20 \mathrm{in} / \mathrm{hr}$. totaled to $187.0 \mathrm{in.}$ Use of the Omega (FPR300) would therefore miss 306.3 inches of rain, or $62.1 \%$ of the total volume of rainfall captured by the platforms. This is the same volume that would be missed by the Decagon (ECRN-50), though it is worth noting that the USGS data measures in increments of $0.01 \mathrm{in} / \mathrm{hr}$. Therefore, comparison between the measurable volume between the Decagon (ECRN-50) and Omega (FPR300) does not consider differences in intensity beyond precision of 2 decimal places. 


\subsection{H-Flume}

Flumes are open-flow hydraulic structures that force flow to a supercritical state such that flow can be related to a water level measurement at a single upstream point. A level sensor such as a pressure transducer or bubbler is installed upstream to collect water level data. Different types of flumes may be used depending on the application, including Parshall flumes, trapezoidal flumes, and $\mathrm{H}$ flumes.

H-flumes were developed by the U.S. Soil Conservation Service (SCS) for measuring agricultural flows. The $\mathrm{V}$-notch design allows for measurement of a wide range of flows. $\mathrm{H}$-flumes are not true flumes- rather, they are a hybrid of a V-notch weir and a flume. Flow through an $\mathrm{H}$-flume is related to head using the following equation:

$$
\log Q=A+B \log h_{a}+C\left[\log h_{a}\right]^{2} \quad \text { Equation } 2
$$

Where $Q$ is flow in $\mathrm{m}^{3} / \mathrm{s}, h_{a}$ is upstream head in meters, and $A, B$, and $C$ are constants found from the rating curve of the specific flume (Gwinn \& Parsons, 1976). An HS-flume with a flume depth of $10 \mathrm{~cm}$ is available at PSU and may be a viable option to quantify runoff from the ecoroof platforms. An HS-flume is the smallest class of H-flumes. The rating curve (Figure 6) and equation for the available HSflume was determined in the PSU hydraulics lab using a velocimeter (Whitlow-Hewett, Personal Communication):

$$
Q=0.0008 e^{0.5375 \cdot h_{a}}
$$

Equation 3. 


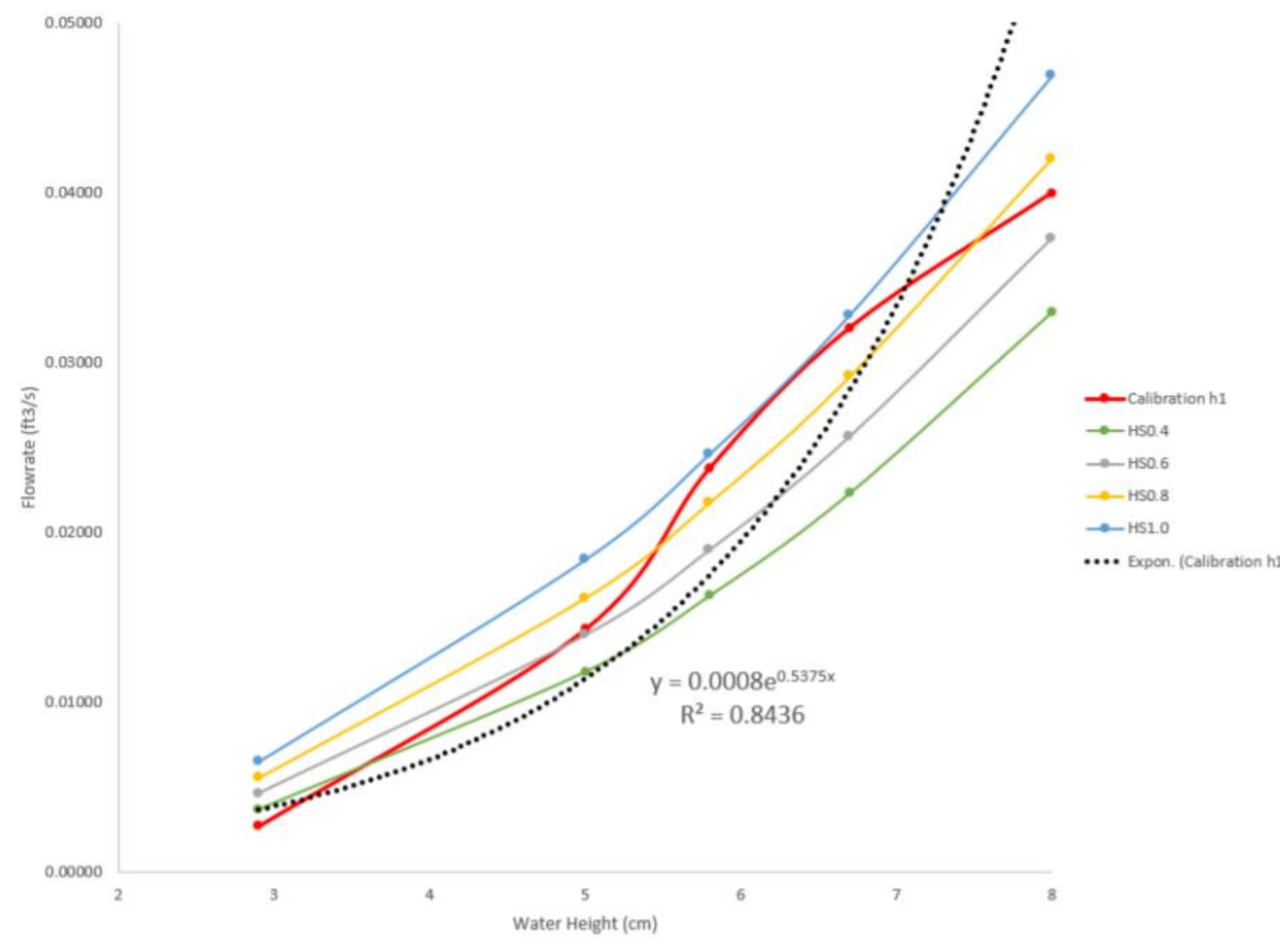

Figure 6. HS-Flume rating curve (red) and line of best fit (dotted black) compared to rating curves for standard HS-Flume sizes (Whitlow-Hewett, Personal Communication).

Where $Q$ is flow in $\mathrm{ft}^{3} / \mathrm{s}$ and $h_{a}$ is upstream head in $\mathrm{cm}$. Whitlow-Hewett cautions that this preliminary calibration deviates from the trend of typical $\mathrm{H}$-flume rating. Further calibration is recommended as the HS-flume does not match geometrical ratios of standard $\mathrm{H}$-flume design. This work will move forward using Whitlow-Hewett's equation to estimate the flow range of the H-flume.

\subsubsection{H-Flume Flow Range}

The upstream head will be measured using a Sigma 950 Bubbler Flowmeter loaned by the City of Portland. This model is specified to measure between $0.003 \mathrm{~m}$ to $3.6 \mathrm{~m}$, or $0.3 \mathrm{~cm}$ to $360 \mathrm{~cm}$. The depth of the flume is $10 \mathrm{~cm}$, so the range considered for this study is $0.3 \mathrm{~cm}$ to $10 \mathrm{~cm}$. When plugged into 
Equation 3 and converted to L/s, these ranges result in a measurable flow range between $0.03 \mathrm{~L} / \mathrm{s}$ to 4.89 L/s. A standard $0.4 \mathrm{ft}$ deep HS-Flume can measure as low as $0.03 \mathrm{~L} / \mathrm{s}$ and as high as $22 \mathrm{~L} / \mathrm{s}$, so we will assume that Equation 3 can be extrapolated for this full flow range (Clemmens et al., 2001).

The flow ranges measurable by the HS-flume and Sigma 950 do not include the lowest expected flow ranges. Similarly to the Decagon (ECRN-50) tipping bucket, the proportion of rainfall detectable by the HS-flume was estimated by comparing the 5-year USGS rainfall data to the measurable flow range of the HS-Flume. Converting the detectable flow range to intensity resulted in a detectable intensity range of $20 \mathrm{in} / \mathrm{hr}$. to $3900 \mathrm{in} / \mathrm{hr}$. The inches of rainfall over the 5 -year period at the USGS Portland Airport rain gage totaled to 493.3 inches, while the readings above $20 \mathrm{in} / \mathrm{hr}$. totaled to $24.7 \mathrm{in}$. Use of this HS-flume would therefore miss 469 inches of rain, or $95 \%$ of the total volume of rainfall captured by the platforms. However, the capturable $5 \%$ includes peak intensity.

\subsection{Comparison}

An overview of the potential solutions was tabulated by the instrument type, mode, minimum flow, maximum flow, price, percentage overlap of the measurable and expected flow range, and percentage detectable volume of rainfall (Table 8). The instruments will be compared by each criterion: ability to measure expected flows, ease of installation, full-pipe flow requirement, and expense. 
Table 8. Comparison of instrument models by minimum and maximum flow, price, and percentage overlap of measurable flow range and expected flow range.

\begin{tabular}{|c|c|c|c|c|c|c|}
\hline Instrument & Model & $\begin{array}{c}\text { Min Flow } \\
(\mathrm{L} / \mathrm{s})\end{array}$ & $\begin{array}{c}\text { Max Flow } \\
\text { (L/s) }\end{array}$ & Price & $\begin{array}{c}\text { \% Flow Range } \\
\text { Overlap }\end{array}$ & $\begin{array}{l}\text { \% Volume } \\
\text { Captured }\end{array}$ \\
\hline Tipping & $\begin{array}{l}\text { Decagon } \\
\text { (ECRN-50) }\end{array}$ & 0.0004 & 0.005 & $\$ 211.00$ & $2.58 \%$ & $37.90 \%$ \\
\hline Bucket & Custom & - & - & - & - & - \\
\hline \multirow{3}{*}{$\begin{array}{l}\text { Impeller } \\
\text { Flowmeter }\end{array}$} & $\begin{array}{c}\text { Omega } \\
\text { (FPR300/310) }\end{array}$ & 0.0045 & 0.315 & $\$ 355.52$ & $97.72 \%$ & $37.90 \%$ \\
\hline & $\begin{array}{c}\text { Omega } \\
\text { (FP-5060) }\end{array}$ & 0.002 & 0.043 & $\$ 428.98$ & $24.47 \%$ & - \\
\hline & $\begin{array}{l}\text { Omega } \\
\text { (FTB300) }\end{array}$ & 0.0005 & 0.005 & $\$ 362.85$ & $2.58 \%$ & - \\
\hline H-Flume & $\begin{array}{c}\text { HS-Flume + } \\
\text { Sigma } 950 \\
\text { Bubbler }\end{array}$ & 0.03 & 4.89 & - & $85.02 \%$ & $5.00 \%$ \\
\hline
\end{tabular}

\subsection{Flow Range}

Figure 7 provides visuals for the overlap expected flow range detectable by each alternative excluding the custom tipping bucket. The chart shows that the Omega (FPR300) impeller flowmeter model has the highest overlap of the expected flows but cannot measure the lowest flows. The H-Flume also cannot measure the lower flows, and the range extends beyond the graph into much higher flows than necessary for the SRTC ecoroof platforms. The Omega (FTB300) and Decagon (ECRN-50) measure a very small percentage of the expected flows at the lowest end of the range. The Omega (FTB300) cannot reach the highest flows nor the lowest flows. Based on these criteria, none of the equipment can measure the full expected flow range. A dual monitoring system is likely necessary to achieve the full flow range. 


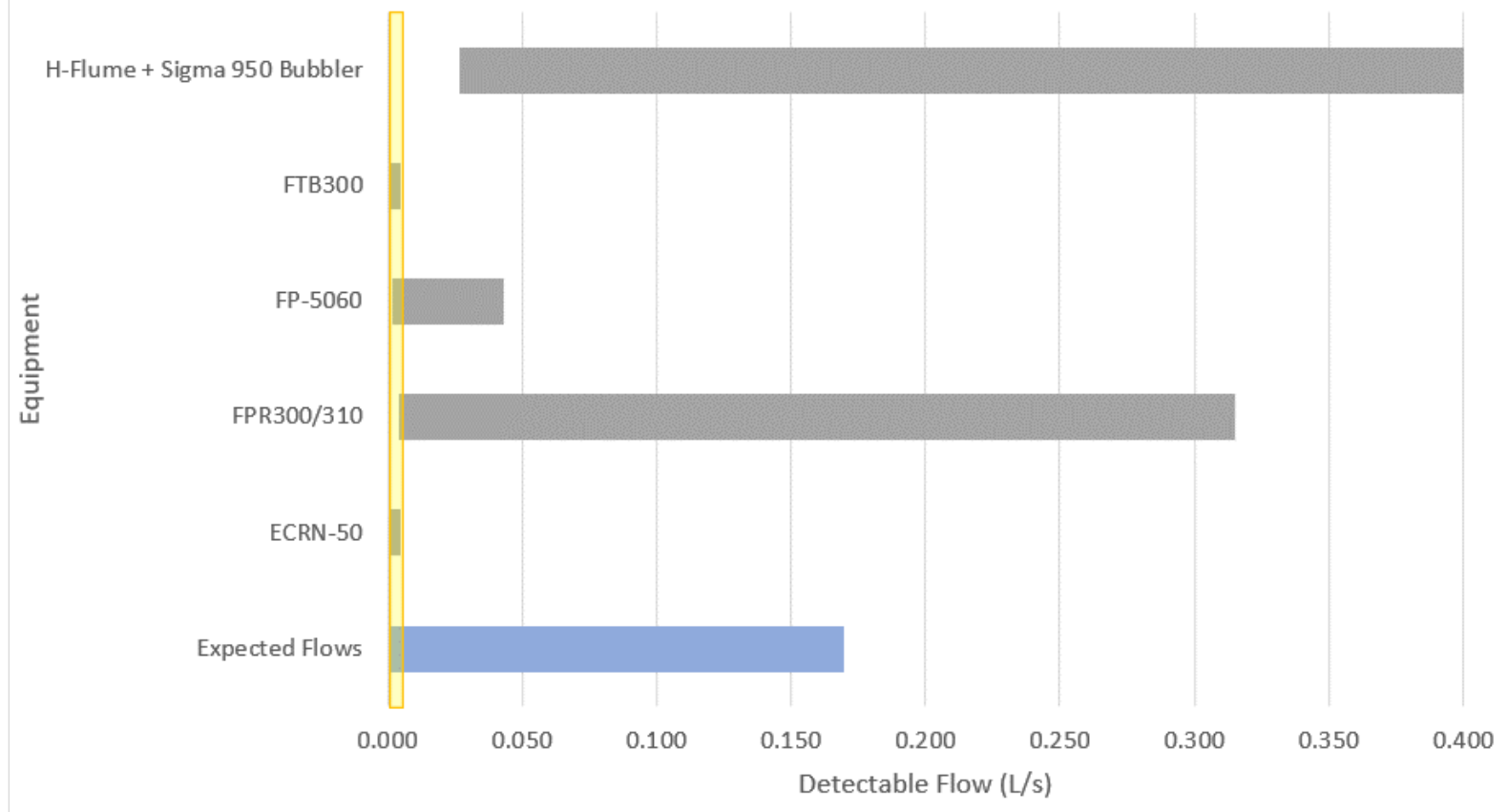

Figure 7. Visual comparison of percentage overlap of measurable flow ranges (gray) of each model and expected flow range (blue). The low flow range of importance for this application is highlighted in yellow.

\subsubsection{Low \& High Flows}

The most common flow rates are $.001 \mathrm{~mL} / \mathrm{s}$ to $.005 \mathrm{~mL} / \mathrm{s}$, so instrumentation that can capture these flow flows is of priority. Assuming $0 \%$ retention in the wet season, instrumentation should ideally be designed to capture flow rates as high as $.170 \mathrm{~L} / \mathrm{s}$. Capturing peak flow may be of interest from a stormwater management perspective as peak flow often overwhelms stormwater infrastructure. While none of the solutions examined can capture the full flow range, some are better suited for the expected low flows of the SRTC ecoroof platforms. The Decagon (ECRN-50) can measure the lowest flows and can capture an estimated $37.90 \%$ volume of rainfall. For an application that is concerned with high flows, the H-flume would likely be the best option. 


\subsubsection{Ease of Installation}

The tipping bucket style rain gage requires inflow into the top of the tipping bucket. This poses a challenge given that the outflow pipes from the ecoroof platforms are at ground level and the Decagon (ECRN-50) is taller than the overflow pipe. Four possible solutions may solve this issue. The first option is to elevate the ecoroof platforms so that the outflow pipe is raised. The second option is to suspend the tipping bucket in the roof drain and direct the flow to the tipping bucket. The third option is to slice off a few centimeters such that the Decagon (ECRN-50) can fit under the overflow pipe. The fourth option is to create a custom tipping bucket. The custom tipping bucket could be designed with a 3D-printable tipper that is specified for the lower flow rates and a short height such that the apparatus can fit beneath the outflow pipe. This design could also be adjusted and applied to different ecoroof platform sites. Another option would be to create a custom tipping bucket. A data logger would need to be specified for the custom tipping bucket. This could be done using advances in technology such as Arduino. The custom tipping bucket option would also give the ability to design at a size that can fit under the ecoroof platform overflow drain. A data logger would need to be specified for the custom tipping bucket. This could be done using advances in technology such as Arduino. The custom tipping bucket option would also give the ability to design at a size that can fit under the ecoroof platform overflow drain. One of these options must be considered to use a tipping bucket for runoff measurement.

The HS-flume is the simplest to install as the platforms are at grade and the flume only needs to be hooked up to the drainage pipe and calibrated with the bubbler. A custom tipping bucket would also be simple to install if it is designed to fit under the overflow pipe. The Decagon (ECRN-50) would be slightly difficult to install as it does not fit under the overflow pipe, but the easiest solution is to shave 
the top such that it can fit. The impeller flowmeters would be difficult to install as they would need a device to force full-pipe flow to work properly.

\subsubsection{Full-Pipe Flow}

Neither the tipping bucket nor the H-flume require full-pipe flow. The impeller flowmeters do require full-pipe flow for proper readings, so they may not be the best option for the expected low flows.

\subsubsection{Cost}

The $\mathrm{H}$-flume is the least expensive option as PSU already owns the $\mathrm{H}$-flume, but additional replicates are necessary to accommodate all four platforms. One Decagon (ECRN-50) is also already owned by PSU, but three more would need to be purchased for all four platforms. The expense of the custom tipping bucket is unknown. The impeller flowmeters are pricey and would add up when installed to four platforms.

All explored solutions were compared based on the criteria discussed (Figure 8). All impeller flowmeters require full-pipe flow and are the most expensive options, so the impeller flowmeters are not the best option for this application. The HS-flume is the simplest to install and can measure a good portion of the expected flow range, but these higher flows only make up $5 \%$ of the total volume of rainfall in Portland based on the USGS rainfall data. The Decagon (ECRN-50) will need to be altered for installation, but the low flows make up almost $38 \%$ of the total rainfall volume. The custom tipping bucket meets the most criteria, making it the top choice for this application. The next best option would be the Decagon (ECRN-50) because it is specified to the expected lower flows. It is also worth noting that 
the literature shows that tipping buckets are often used on the experimental scale, further supporting the choice of a tipping bucket for the SRTC ecoroof platforms.

\begin{tabular}{|c|c|c|c|c|c|c|}
\hline Criteria & $\begin{array}{l}\text { Tipping } \\
\text { Bucket } \\
\text { (Decagon } \\
\text { ECRN-50) }\end{array}$ & $\begin{array}{l}\text { Tipping } \\
\text { Bucket } \\
\text { (Custom) }\end{array}$ & $\begin{array}{l}\text { HS-Flume + } \\
\text { Level Sensor }\end{array}$ & $\begin{array}{l}\text { Impeller } \\
\text { Flowmeter } \\
\text { (Omega } \\
\text { FPR300) }\end{array}$ & $\begin{array}{l}\text { Impeller } \\
\text { Flowmeter } \\
\text { (Omega } \\
\text { FP5060) }\end{array}$ & $\begin{array}{l}\text { Impeller } \\
\text { Flowmeter } \\
\text { (Omega } \\
\text { FTB300) }\end{array}$ \\
\hline $\begin{array}{l}\text { Measures Full } \\
\text { Expected Flow } \\
\text { Range }\end{array}$ & $\mathrm{x}$ & $?$ & $x$ & $x$ & $x$ & $x$ \\
\hline $\begin{array}{c}\text { Measures Lower } \\
\text { Flows }(0.001-0.005 \\
\mathrm{L} / \mathrm{s})\end{array}$ & $\checkmark$ & $\checkmark$ & $x$ & $\checkmark$ & $\checkmark$ & $x$ \\
\hline $\begin{array}{c}\text { Measures Higher } \\
\text { Flows (0.005-0.170 } \\
\text { L/s) }\end{array}$ & $x$ & $?$ & $\checkmark$ & $x$ & $x$ & $\checkmark$ \\
\hline $\begin{array}{l}\text { Full Pipe Flow Not } \\
\text { Required }\end{array}$ & $\checkmark$ & $\checkmark$ & $\checkmark$ & $x$ & $x$ & $x$ \\
\hline Ease of Installation & $x$ & $\checkmark$ & $\checkmark$ & $x$ & $x$ & $x$ \\
\hline Cost & $\$ 211.00$ & $\mathrm{n} / \mathrm{a}$ & $\mathrm{n} / \mathrm{a}$ & $\$ 355.52$ & $\$ 248.98$ & $\$ 362.85$ \\
\hline
\end{tabular}

Figure 8. Criteria checklist for all instruments.

\subsection{Conclusion}

Based on the site conditions, the suggested runoff monitoring instrument for application on the SRTC ecoroof platforms is the custom tipping bucket, with the Decagon (ECRN-50) coupled with the HFlume as a runner up. The custom tipping bucket would allow for the flow range to be specified to the expected flow rates from the ecoroof platforms. However, if the resources are not available for creation of a custom tipping bucket, the Decagon (ECRN-50) is the second-best option as it can capture the lower flow ranges of interest. It is worth noting that while the HS-flume only captures the $5 \%$ of the rainfall volume based on historical data, increased rainfall intensity due to climate change may change the hydrological conditions of the Pacific Northwest such that higher flows will be of more concern. The HSflume may also be useful from a stormwater management perspective as peak flow often overwhelms stormwater infrastructure and is the main area of concern. 
This study has many limitations. First and foremost, there is uncertainty around the area of the SRTC experimental platforms due to the COVID-19 pandemic resulting in limited access to campus for measurements. This study is not a comprehensive evaluation of all methods for runoff measurement and future research should explore other instrumentation such as electromagnetic flowmeters, ultrasonic sensors for open channel flow, and collection buckets as options for ecoroof platform runoff monitoring as used in Jahanfar et al's (2018) and Wong \& Jim's (2014) research. Furthermore, although runoff is evaluated at the storm level, within any given storm a variety of intensities may occur. This study only looked at intensities and did not group them by storm. Additionally, the lower limit of the Hflume equation is assumed based on a single source and should be tested to determine the actual lower limit of the flume.

Future research on the SRTC ecoroof platforms is encouraged to target design of a custom tipping bucket that can capture the low flow ranges discussed in this work. The custom tipping bucket may additionally be designed such that it can be implemented on multiple ecoroof platforms across campus. Additionally, the HS-flume needs to be re-calibrated and installed with the Sigma 950 Bubbler. Once runoff instrumentation is established at the SRTC ecoroof platforms, future students and faculty may use the instrumentation for a wide range of educational and scholarly work.

Runoff instrumentation is highly dependent on site conditions and application. This study focuses on experimental scale ecoroof platforms in the Pacific Northwest and the suggested instrumentation is based on this specific site's needs and the assumptions stated in this work. Solutions will vary between sites depending on many factors including the location's hydrology, the scale and geometry of the ecoroof, the flow ranges of interest, and more. 


\section{References}

Berkompas, B., Marx, K. W., Wachter, H. M., Beyerlein, D., \& Spencer, B. (2008). A Study of Green Roof Hydrologic Performance in the Cascadia Region. Low Impact Development for Urban Ecosystem and Habitat Protection. https://doi.org/10.1061/41009(333)8

Brabec, E., Schulte, S., \& Richards, P. L. (2002). Impervious Surfaces and Water Quality: A Review of Current Literature and Its Implications for Watershed Planning. Journal of Planning Literature, 16(4). https://doi.org/https://doi.org/10.1177/088541202400903563

Bureau of Environmental Services, 2020 Sewer and Drainage Facilities Design Manual (2020). Portland, OR; City of Portland.

Bureau of Environmental Services, 2020 Stormwater Management Manual (2020). Portland, OR; City of Portland.

Clemmens, A. J., Wahl, T. L., Bos, M. G., \& Replogle, J. A. (2001). Water Measurement with Flumes and Weirs. International Institute for Land Reclamation and Improvement.

Gwinn, W. R., \& Parsons, D. A. (1976). Discharge equations For $\mathrm{Hs}, \mathrm{H}$, and HL Flumes. Journal of the Hydraulics Division, 102(1), 73-88. https://doi.org/10.1061/jyceaj.0004474

Hutchinson, D., Abrams, P., Retzlaff, R., \& Liptan, T. (2003). Stormwater Monitoring Two Ecoroofs in Portland, Oregon, USA. City of Portland, Bureau of Environmental Services.

Jahanfar, A., Drake, J., Sleep, B., \& Gharabaghi, B. (2018). A modified FAO Evapotranspiration Model for Refined Water Budget Analysis for Green Roof Systems. Ecological Engineering, 119, 45-53. https://doi.org/10.1016/j.ecoleng.2018.04.021

Karamouz, M., Hosseinpour, A., \& Nazif, S. (2011). Improvement of Urban Drainage System Performance under Climate Change Impact: Case Study. Journal of Hydrologic Engineering, 16(5), 395-412. https://doi.org/10.1061/(asce)he.1943-5584.0000317

Maclvor, J. S., Margolis, L., Puncher, C. L., \& Carver Matthews, B. J. (2013). Decoupling Factors Affecting Plant Diversity and Cover on Extensive Green Roofs. Journal of Environmental Management, 130, 297-305. https://doi.org/10.1016/j.jenvman.2013.09.014

Oregon Department of Environmental Quality, National Pollutant Discharge Elimination System Municipal Separate Storm Sewer System (MS4) Discharge Permit (2011). Portland, OR; Oregon Department of Environmental Quality.

Rainfall at Airport Way \#2 Rain Gage. USGS. (n.d.). https://or.water.usgs.gov/nonusgs/bes/airport_way.html.

Rowe, D. B., VanWoert, N. D., Andresen, J. A., Rugh, C. L., Fernandez, R. T., \& Xiao, L. (2005). Green Roof Stormwater Retention: Effects of Roof Surface, Slope, and Media Depth. Journal of Environmental Quality, 34(3), 1036-1044. https://doi.org/10.2134/jeq2004.0364 
Spolek, G. (2008). Performance monitoring of three ecoroofs in Portland, Oregon. Urban Ecosystems, 11(4), 349-359. https://doi.org/10.1007/s11252-008-0061-z

Starry, O. (2013). The comparative effects of three Sedum species on green roof stormwater retention (dissertation). University of Maryland (College Park, Md.), College Park, MD.

Whitlow-Hewett, M. (Personal Communication, 2021). Determining the Effectiveness of Using an HFlume to Measure Eco-Roof Runoff based on Calibration Data.

Wong, G. K. L., \& Jim, C. Y. (2014). Quantitative hydrologic performance of extensive green roof under humid-tropical rainfall regime. Ecological Engineering, 70, 366-378.

https://doi.org/10.1016/j.ecoleng.2014.06.025 